\title{
Employment of Inappropriate Technologies in Agriculture: a Recipe for Lower Production
}

\author{
Kingsley Osei (Corresponding author) \\ Crops Research Institute, Box 3785, Kumasi, Ghana \\ E-mail: oseikingsley4@gmail.com \\ Solomon Gyasi-Boakye \\ Crops Research Institute, Box 3785, Kumasi, Ghana \\ E-mail: solomongyasiboakye@yahoo.com \\ Emmanuel Afriyie \\ Crops Research Institute, Box 3785, Kumasi, Ghana \\ E-mail: eafriyie@hotmail.com \\ Adelaide Agyeman \\ Crops Research Institute, Box 3785, Kumasi, Ghana \\ E-mail: amaagyeman@gmail.com
}

Received: June 22, 2013 Accepted: July 6, 2013

doi:10.5296/jas.v1i2.4112 URL: http://dx.doi.org/10.5296/jas.v1i2.4112

\begin{abstract}
Maize production practices of four Farmer Based Organizations in the Kpando District of the Volta Region of Ghana were studied prior to the training in Commercial Development and Good Agricultural Practices for the Farmer Based Organizations. Demographic characteristics of respondents and the rate of adoption of available technologies were analyzed using frequencies, percentages and means while regression analysis was used for the yield data. Males constituted $60 \%$ of the population whilst $40 \%$ were females. The district had a relatively young farming population with $56 \%$ of the farmers below 45 years. The level of education of
\end{abstract}


respondents was low. Eighty-two percent of respondents had not attained senior high school education. Majority (56\%) of respondents had been farming for less than 20 years. The rate of adoption of technologies was low and maize yields were very low averaging $0.375 \mathrm{t} / \mathrm{ha}$ in the district. There were no differences in yields amongst the four FBOs. The yield of farmers could increase significantly when farmers adopt improved agricultural technologies.

Keywords: Adoption of technologies, Ghana, Millennium Development Authority, Volta region, Zea mays.

\section{Introduction}

Agriculture is the main economic activity of the majority of the Ghanaian population as it contributes more than 35\% Gross Domestic Product and employs about 55\% of Ghana's labour force (CIA, 2009). However, the country still remains highly dependent on food imports from developed countries (EIU, 2007). This deplorable situation informed Ghana's decision to seek for financial assistance from the US government to revamp the country's agricultural industry. On August 1, 2006, the US and Ghana governments signed an agreement called the Ghana Compact under which the US offered Ghana a grant of US $\$ 208.8 \mathrm{~m}$ for agricultural transformation for a 5 year period. In Ghana, the programme was administered by the Millennium Development Authority (MiDA). The Compact seeks to achieve poverty reduction and economic growth through rural transformation led by Farmer Based Organizations (FBOs) (MiDA, 2009).

Traditionally, peasant farmers in Ghana receive periodic extension advice from the Ministry of Food and Agriculture during which interactions; improved farming technologies are imparted to them to increase food productivity. However, productivity levels remained abysmally low. MiDA therefore organized a series of training for farmers in three intervention zones; Northern Agricultural, Afram Basin and Southern Horticultural Zones to introduce farmers to the concepts of Commercial Development for FBOs and GAP. The main purpose of the MiDA training however, was to increase food productivity. The training programme, which was conducted in the year 2010, comprised a six week intensive Capacity Building followed by a three week Technical training and three weeks of hands-on activities. The Capacity Building modules prepared participants to take control of their associations, to help them prepare farm records, and enter into proper contract agreements with prospective customers among others, while the technical training strengthened their knowledge and skills in good agricultural practices.

In the Southern Horticultural Zone, one hundred and ninety three (193) farmers in the Kpando district of the Volta region belonging to four FBOs namely; Dornenyo Farmers Association (DFA), Torwogbe Farmers Association (TFA), Milenorvisi Farmers Association (MFA) and Foundation Vegetable Growers Co-operative Society (FVGCS) whose major occupation was maize production, participated in the MiDA sponsored training facilitated by the Council for Scientific and Industrial Research-Crops Research Institute (CSIR-CRI) of Ghana.

Maize (Zea mays L.) is an important source of carbohydrates which compares favourably with root and tuber crops and similar in energy value to dried legumes. Furthermore, maize oil 
contains a high level of polyunsaturated fatty acids and natural antioxidants (Okoruwa, 1996). The cereal crop is an important staple in Ghana, particularly in the Volta region where it is used in the preparation of two favourite traditional dishes "Banku" and "Akple". However, the productivity of maize in Ghana is generally low, averaging a meagre $1.55 \mathrm{t} / \mathrm{ha}^{-1}$ (PPMED, 1998).

The adoption of GAP could go a very long way in increasing productivity and eventually raising the standard of living of the people. The objectives of the study therefore were; to identify the demographic characteristics of the respondents, the technologies adopted by respondents prior to the MiDA training to "fill up" technological gaps if any to boost maize production and productivity, to determine the extent of technology adoption by respondents and to compare the yields of the four FBOs in the Kpando district prior to the MiDA training.

\section{Research Methods}

The study was carried out in four communities in the Kpando district of the Volta region. The communities were; Fu/Konda, Wusuta Kpebe, Vakpo New Adomi and Wusuta Torkpeta where Dornenyo Farmers Association (DFA), Torwogbe Farmers Association (TFA), Milenorvisi Farmers Association (MFA) and Foundation Vegetable Growers Co-operative Society (FVGCS) were located respectively. Members of the four farmer associations were selected through simple random sampling technique. The sample size was 193 farmers in the four FBOs with the following distribution; DFA 48, FVGCS 47, MFA 48 and TFA 50 members.

Prior to the training of farmers under the MiDA facility, it became necessary to know their level of operation, technologies employed and their vision. Such background information was essential to tailor the training to satisfy the needs of the farmers. Therefore; gender, age, level of education, farmers experience in farming, technology adoption and yield were analyzed. Data was collected by the use of a semi-structured interview and a questionnaire. Both open and closed ended questionnaires were designed, pre-tested, revised and administered to the population in the four communities. To make sure reliable responses were given by respondents, questions asked earlier were later asked again to test the veracity of responses. To gain the confidence of respondents to open up to the interviewer, the purpose of the study was well explained to them. Frequencies, percentages and means were used to analyze data on the demographic characteristics of respondents and adoption of technologies while GenStat regression was used to analyze the unbalanced design of the yield data.

\section{Results and discussion}

\subsection{Demographic Characteristics of Respondents}

A set of factors have been identified that influence the adoption of new technologies by farmers (Adekoya and Babaleye, 2009; Rogers, 1995). In this study; gender, age, level of education and farmers experience in farming were considered. 
Table 1. Demographic characteristics of respondents

\begin{tabular}{|c|c|c|c|c|c|c|c|c|c|}
\hline Variables & \multicolumn{2}{|c|}{$\begin{array}{l}\text { DFA } \\
\text { Freq. Percent }\end{array}$} & \multicolumn{2}{|c|}{$\begin{array}{l}\text { TFA } \\
\text { Freq. Percent }\end{array}$} & \multicolumn{2}{|c|}{$\begin{array}{l}\text { MFA } \\
\text { Freq. Percent }\end{array}$} & \multicolumn{2}{|c|}{$\begin{array}{l}\text { FVGCS } \\
\text { Freq. Percent }\end{array}$} & $\begin{array}{l}\text { TOTAL } \\
\text { Frequency }\end{array}$ \\
\hline $\begin{array}{l}\text { Gender } \\
\text { M } \\
\text { F }\end{array}$ & $\begin{array}{l}29 \\
19\end{array}$ & $\begin{array}{l}60.4 \\
39.6\end{array}$ & $\begin{array}{l}28 \\
22\end{array}$ & $\begin{array}{l}56.0 \\
44.0\end{array}$ & $\begin{array}{l}28 \\
20\end{array}$ & $\begin{array}{l}58.3 \\
41.7\end{array}$ & $\begin{array}{l}31 \\
16\end{array}$ & $\begin{array}{l}66.0 \\
34.0\end{array}$ & $\begin{array}{l}116 \\
77\end{array}$ \\
\hline $\begin{array}{l}\text { Age (Years) } \\
<30 \\
31-45 \\
46-60 \\
>60\end{array}$ & $\begin{array}{l}8 \\
20 \\
18 \\
2\end{array}$ & $\begin{array}{r}16.7 \\
41.7 \\
37.5 \\
4.1\end{array}$ & $\begin{array}{l}10 \\
24 \\
9 \\
7\end{array}$ & $\begin{array}{l}20.0 \\
48.0 \\
18.0 \\
14.0\end{array}$ & $\begin{array}{l}4 \\
25 \\
17 \\
2\end{array}$ & $\begin{array}{r}8.3 \\
52.1 \\
35.4 \\
4.2\end{array}$ & $\begin{array}{l}0 \\
17 \\
28 \\
2\end{array}$ & $\begin{array}{r}0 \\
36.2 \\
59.6 \\
4.2\end{array}$ & $\begin{array}{l}22 \\
86 \\
72 \\
13\end{array}$ \\
\hline $\begin{array}{l}\text { Educational } \\
\text { Level } \\
\text { None } \\
\text { MSLC } \\
\text { JHS } \\
\text { SHS } \\
\text { Tertiary }\end{array}$ & $\begin{array}{l}4 \\
21 \\
11 \\
6 \\
6\end{array}$ & $\begin{array}{r}8.3 \\
43.8 \\
22.9 \\
12.5 \\
12.5\end{array}$ & $\begin{array}{l}13 \\
21 \\
9 \\
5 \\
2\end{array}$ & $\begin{array}{r}26.0 \\
42.0 \\
18.0 \\
10.0 \\
4.0\end{array}$ & $\begin{array}{l}9 \\
18 \\
13 \\
5 \\
3\end{array}$ & $\begin{array}{r}18.7 \\
37.5 \\
27.1 \\
10.4 \\
6.3\end{array}$ & $\begin{array}{l}11 \\
27 \\
1 \\
4 \\
4\end{array}$ & $\begin{array}{r}23.4 \\
57.5 \\
2.1 \\
8.5 \\
8.5\end{array}$ & $\begin{array}{l}37 \\
87 \\
34 \\
20 \\
15\end{array}$ \\
\hline $\begin{array}{l}\text { Farming } \\
\text { Experience } \\
<9 \\
10-20 \\
21-32 \\
33-44 \\
>44 \\
\end{array}$ & $\begin{array}{l}11 \\
14 \\
16 \\
4 \\
3 \\
\end{array}$ & $\begin{array}{r}22.9 \\
29.2 \\
33.3 \\
8.3 \\
6.3 \\
\end{array}$ & $\begin{array}{l}7 \\
22 \\
9 \\
9 \\
3 \\
\end{array}$ & $\begin{array}{r}14.0 \\
44.0 \\
18.0 \\
18.0 \\
6.0 \\
\end{array}$ & $\begin{array}{l}9 \\
18 \\
10 \\
7 \\
4 \\
\end{array}$ & $\begin{array}{r}19.8 \\
37.5 \\
20.8 \\
14.6 \\
8.3 \\
\end{array}$ & $\begin{array}{l}4 \\
23 \\
11 \\
7 \\
2 \\
\end{array}$ & $\begin{array}{r}8.5 \\
48.9 \\
23.4 \\
14.9 \\
4.3 \\
\end{array}$ & $\begin{array}{l}31 \\
77 \\
46 \\
27 \\
12 \\
\end{array}$ \\
\hline
\end{tabular}

DFA-Dornenyo Farmers Association; TFA-Torwogbe Farmers Association; MFA-Milenorvisi Farmers Association; FVGCS-Foundation Vegetables Growers Co-operative Society.

Majority of the farmers in maize production approximately $(60 \%)$ were males while approximately $40 \%$ were females (Table 1). This result is in contrast with the situation in Kenya, Malawi, Sierra Leone, Zambia and Zimbabwe where women predominate in food production but receive less credit directed at small holders (Bullock, 1993). In Ghana, the role of women in agricultural production remains significant. After production, women play the vital role of marketing the produce to make the production effort meaningful.

Majority of farmers, approximately 56\% were below 45 years (Table 1). This situation is promising and insurance for maize production in the Kpando district. The high number of relatively young people engaged in maize production also guarantees labour which is a major problem in the agricultural industry in Ghana. Age is negatively associated with adoption; younger farmers are more likely to adopt new technologies and or are more likely to be early adopters (D'Souza et al., 1993). Good agricultural practices could more easily be adopted by the relatively young farming population in the district through informal training programmes.

The level of education among the respondents in the district was significantly low as approximately $82 \%$ have not attained senior high school education (Table 1). Education is positively and significantly associated with adoption (D'Souza et al., 1993). The higher the farmer's educational background, the higher the propensity to adopt technological innovations. Low level of education as obtained in the Kpando district, had been reported to affect the level of technology adoption and skills acquisition among farmers (Oyekale and Idjesa, 2009). 
Illiterate farmers are slow to adopt technologies if they would adopt at all.

The relatively young age of the respondents implied that most (56\%) have been in the farming business for less than 20 years (Table 1). Obviously, farmers could therefore be described as inexperienced. Low level of education coupled with inexperience could impact negatively on productivity. It was therefore not surprising that yields were extremely low in the district (Table 3).

\subsection{Adoption of Technologies}

The Directorate of the Ministry of Food and Agriculture indicated to the facilitator that, ten agricultural technologies were available to the members of the four FBOs. However, all the farmers were aware of $(60 \%)$ of these technologies which were: improved varieties, timely sowing, row planting, fertilizer application, timely harvesting and post harvest handling.

Table 2. Technologies adopted by the 193 members of the four FBOs in the Kpando district of the Volta region

\begin{tabular}{|l|lr|lr|l|}
\hline Available Technologies & \multicolumn{2}{|c|}{ Awareness } & \multicolumn{2}{c|}{ Application } & Rate of \\
& Yes & No & Yes & No & Adoption \\
\hline Improved varieties & 193 & 0 & 14 & 179 & 7.3 \\
Seed rate $(9 \mathrm{~kg} /$ acre) & 9 & 184 & 9 & 184 & 4.7 \\
Seed treatment before sowing & 190 & 3 & 0 & 193 & 0 \\
Timely sowing & 193 & 0 & 193 & 0 & 100 \\
Recommended spacing $(80 \times 80 \mathrm{~cm})$ & 9 & 184 & 9 & 184 & 4.7 \\
Row planting & 193 & 0 & 67 & 12667 & 34.7 \\
Fertilizer application & 193 & 0 & 126 & & 34.7 \\
Diseases and pests management & 9 & 184 & 9 & 184 & 4.7 \\
Timely harvesting & 193 & 0 & 117 & 76 & 60.6 \\
Post harvest handling & 193 & 0 & 14 & 179 & 7.3 \\
\hline
\end{tabular}

Of the six technologies known to farmers, only one of them, timely sowing had been adopted by all farmers (Table 2). Adoption of some essential technologies was extremely low which affected yield in the district. For instance, use of improved varieties, optimum seed rate, seed treatment before sowing, recommended spacing and diseases and pests management recorded less than $10 \%$ adoption. Improved varieties yield higher than local varieties therefore, the continued use of local varieties resulted in lower maize yields.

Failure to adopt the recommended seed rate of $9 \mathrm{~kg} / \mathrm{acre}$ meant farmers either used little or too much seed for an acre of field in either case, lower yields could result. Maize seed was not treated by all farmers which meant that rodents and soil arthropods attack could result in un-germinated hills which could affect yield. Less than $5 \%$ of farmers adopted the recommended spacing of $80 \times 40 \mathrm{~cm}$. Failure to use the recommended spacing could impact negatively on yield since yield is a function of plant population (Akbar et al., 2010; Wiersma, 2002). Less than $5 \%$ of the farmers in the Kpando district managed diseases and pests which impacted negatively on yield (Table 2). 


\subsection{Yield of Maize}

Yields in general were extremely low in the district averaging 1.5 bags / acre. In Ghana, 14 bags /acre has been reported from Research fields (Sallah, 1997). Farmers could have at least realized half the yield of Researchers if they adopted the available technologies. For instance, Ennin and Dapaah (2008) observed that maize production in the country was characterized by no or little fertilizer usage. The current continuous cropping system practiced in most parts of the country necessitates judicious application of fertilizers for economic returns.

Table 3. Average yield/acre of maize of farmers in the four FBOs in the Kpando district before their participation in the MiDA sponsored training

\begin{tabular}{|l|l|l|l|}
\hline FBOs error \\
\hline Dornenyo Farmers Association & $\mathrm{N}$ & Mean & $\begin{array}{l}\text { Standard } \\
\text { differences }\end{array}$ \\
Torwogbe Farmers Association & 48 & 1.51 & 0.09 \\
Milenorvisi Farmers Association & 50 & 1.46 & 0.08 \\
Foundation Vegetables Growers Co-operative & 48 & 1.59 & 0.09 \\
Society & & & 0.09 \\
\hline
\end{tabular}

$\mathrm{N}$ - Population of the respective Farmer Based Organizations (FBOs).

There were no differences in yields amongst the four Farmer Based Organizations production levels. The yield of 1.59 bags/acre recorded by MFA was not different from 1. 48 bags/acre recorded by FVGCS. The significantly low yields recorded by the farmers could be attributed in part to the low adoption rate of available technologies. The adoption of technologies such as improved varieties, recommended seed rate, spacing, fertilizer application, seed treatment before sowing and diseases and pests management could impact positively on yield of maize.

\section{Conclusion}

Adoption of available agricultural technologies was very low in the district which impacted negatively on agricultural production and productivity. Research-extension linkage must be further strengthened for the dissemination of research findings to the teeming farming population to increase production levels. Technologies such as improved crop varieties, application of fertilizers, post harvest management and others require sufficient injection of capital. Therefore, the institution of credit schemes for farmers could complement the adoption of available technologies for the realization of high profits.

\section{Acknowledgement}

Authors are most grateful to the Millennium Development Authority (MiDA) for the financial support for this study.

\section{References}

Adekoya, E. A., \& Babaleye, T. (2009). Consistency of technology adoption among farmersin Northern Nigeria. Journal of Food, Agriculture and Environment, 7, 457-460. 
Akbar, A., Pasha, G. R., \& Aslam, M. (2010). Yield-density rapports: A nonparametric regression approach. International Research Journal of Finance and Economics, 43, 183-187.

Bullock, S. (1993). Women and work, women and world development series, London: Zed Publications.

D’Souza, G., Cyphers, D. \& Phipps, T. (1993). Factors affecting the adoption of sustainable agricultural practices. Agricultural and Resource Economics Review, 159-165.

CIA. (2009). World Fact Book, Central Intelligence Agency, retrieved on 12/10/2011 at http://en.wikipedia.org/wiki/The_World Fact book

EIU. (2007). Country Profile: Ghana, Economist Intelligence Unit, London.

Ennin, S. A., \& Dapaah, H. K. (2008). Legumes in sustainable maize and cassava cropping systems in Ghana. Agricultural and Food Science Journal of Ghana, 7, 519-540.

MiDA. (2009). Millennium Challenge Account, Millennium Development Authority, retrieved on 11/10/2011 at http://mccgov.com.gh.html.

Okoruwa, A. (1996). Nutrition and quality of maize. International Institute of Tropical Agriculture. Available from http://www.iita.org

Oyekale, A. S., \& Idjesa, E. (2009). Adoption of improved maize seeds and production efficiency in River State, Nigeria. Academic Journal of Plant Science, 2, 44-50.

PPMED. (1998). Annual sample survey of agriculture, Ghana, 1997. Regional and district cropped area, yield and production estimates. Agricultural Statistics and Census Division, Policy Planning, Monitoring and Evaluation Department, Ministry of Food and Agriculture, Accra.

Rogers, E. M. (1995). Diffusion of innovation ( $4^{\text {th }}$ edition). New York: The Free Press.

Sallah, P. Y. K., Twumasi-Afriyie, S., Asiedu, E. A., Obeng-Antwi, K., Boa-Amponsem, K., Ahenkora, K., Agyemang, A., \& Lampoh, E. K. (1997). Development and release of Dodzi, an extra-early maturing maize variety in Ghana. Crops Research Institute, Kumasi, Ghana. Mimeograph 28 pp.

Wiersma, J. J. (2002). Determining an optimum seeding rate for spring wheat in Northwest Minnesota. Crop Management. http://dx.doi.org/10.1094/CM-2002-0510-01-RS

\section{Copyright Disclaimer}

Copyright reserved by the author(s).

This article is an open-access article distributed under the terms and conditions of the Creative Commons Attribution license (http://creativecommons.org/licenses/by/3.0/). 